\title{
MICROBIOLOGICAL ANALYSIS OF BILE IN PATIENTS WITH BENIGN AND MALIGNANT BILIOPANCREATIC DISEASES AND ITS CONSEQUENCES
}

\author{
José Roberto ALVES'1, Rodrigo do Carmo SILVA², Sâmea Costa Pinheiro GUERRA², \\ Tiago Tavares de FREITAS ${ }^{2}$, Dyego Leandro Bezerra de SOUZA ${ }^{3}$ and Enio Campos AMICO${ }^{1}$
}

Received 27/12/2015

Accepted 22/3/2016

ABSTRACT - Background - Bactibilia has several consequences to human health. Objetive - Assessing the bile microbiology of patients with biliopancreatic diseases in order to identify bacteria and their possible infectious complications. Methods - Retrospective study of 30 bile culture samples from patients with benign and malignant biliopancreatic diseases. The samples were assessed to set the bile microbiological flora and to search for its possible link with comorbidity, carcinogenesis and postoperative infectious complications. Results - Thirty bile samples from patients at mean age $\approx 57.7$ years, mostly female $(\mathrm{n}=18)$, were assessed. Bactibilia was found in 12 cases, mostly in patients with benign diseases $(n=8)$, older than 50 years $(n=23)$ and female $(n=10)$. Adenocarcinoma of the duodenal papilla $(n=9)$ and cholelithiasis $(n=8)$ were the most common diseases. Escherichia coli $(n=5)$ and Klebsiella sp $(n=3)$ were predominantly found in patients with benign diseases; and Klebsiella sp $(\mathrm{n}=2)$ and Streptococcus $\mathrm{sp}(\mathrm{n}=2)$ were prevalent in cancer patients. There were postoperative infectious complications in seven cases, five of them in bactibilia-associated patients $(P=0.084)$. Conclusion - Bactibilia was found in 12 samples and Escherichia coli and Klebsiella sp were most often identified in patients with benign diseases, as well as Streptococcus sp and Klebsiella sp in cancer patients. There was a trend of higher postoperative infectious complication incidence in patients with bactibilia.

HEADINGS - Microbiology. Bile. Cholecystectomy. Postoperative complications. Carcinogenesis.

\section{INTRODUCTION}

The bile is a lipid-rich sterile solution produced in the liver ${ }^{(2)}$ and it may be colonized by bactibilia, through the ascending path, due to the breakdown of human defense mechanisms during surgery or endoscopy ${ }^{(13,27)}$. The presence of these bacteria may be associated with the presence of any foreign body inserted in the biliary system such as a biliary catheter. The bacteria may also come through the hematogenic pat $^{(27)}$. Furthermore, the chronic biliary obstruction may negatively influence the body defense mechanisms by increasing the pressure within the biliary ducts. Consequently, this obstruction becomes an important risk factor for the development of cholangitis ${ }^{(27)}$.

Moreover, bactibilia may have other consequences such as higher postoperative complication incidence $^{(1,7,8,15,20,24)}$, mainly of infectious complications. Thus, they lead to prolonged hospitalization, to the need for antibiotics-based therapy and, consequently, to higher $\operatorname{costs}^{(7,8,20,24)}$. Thus, the antibiotic prophylaxis helps lowering the postoperative infectious complication rates ${ }^{(15,20)}$.

Likewise, patients with comorbidities such as diabetes mellitus are prone to bactibilia, since diabetes could increase the risk of infection in patients with biliopancreatic diseases ${ }^{(5)}$.

Finally, some studies have shown a possible link between bactibilia and the emergence of malignant neoplasms or cancer, i.e., carcinogenesis ${ }^{(6,9,10,16,17,25,26)}$. Nevertheless, the current medical literature shows little definite information about this bacteria ${ }^{(16,25)}$. In theory, the presence of bacteria in the bile associated with the carcinogenesis process may result from chronic inflammation ${ }^{(10,16,26)}$, as well as from the toxins and metabolites produced by microorganisms; therefore, the presence of these bacteria would result in malignant epithelial transformation ${ }^{(12,16,22)}$. Besides, such process may be related to the presence of specific bacteria such as Salmonella typhi and Salmonella paratyphi,

Departamento de Medicina Integrada, Faculdade de Medicina, Universidade Federal do Rio Grande do Norte, RN, Brasil. 2 Faculdade de Medicina, Universidade Federal do Rio Grande do Norte, RN, Brasil; ${ }^{3}$ Saúde Coletiva, Universidade Federal do Rio Grande do Norte, RN, Brasil.

Correspondence: José Roberto Alves. Departamento de Medicina Integrada, Faculdade de Medicina, Universidade Federal do Rio Grande do Norte. Av. Nilo Peçanha, 620. Petrópolis - CEP: 59012-300 - Natal, RN, Brasil. E-mail: joserobertoalves1980@gmail.com 
which are associated with gallbladder cancer ${ }^{(12,16,17,22,23,25)}$, as well as Helicobacter pylori, which are associated with cancer in the pancreas ${ }^{(18,29)}$ and in the bile ducts ${ }^{(16,29,30)}$. This process may also be associated with unknown factors that have not yet been explained or understood ${ }^{(12,25)}$.

Thus, the aim of the current study is to set the bacterial flora of patients with biliopancreatic diseases in order to search for possible consequences caused by the presence of bactibilia.

\section{METHODS}

The present retrospective study analyzed the microbiological test results from 93 bile samples collected through gallbladder wall puncture using Jelco ${ }^{\circledR}$ (Becton, Dickinson and Company, BD, Brazilian branches), 14-gauge size. The procedure was performed during the intraoperative period, right before the performance of elective cholecystectomies (by laparotomy or videolaparoscopy), required for patients with benign and malignant biliopancreatic diseases (i.e., diseases of the gallbladder, bile ducts, pancreas and duodenal papilla). The patients with choledocholithiasis or cancer had their bile collected right before the cholecystectomy, as well as before the responsible surgeon proceeded with the other surgical procedures necessary to treat these biliopancreatic diseases, namely: choledochotomy, partial gastrectomy, duodenectomy, partial pancreatectomy, among others. The bile samples were collected from March 2007 to March 2015 and sent to the clinical analysis laboratory of Onofre Lopes University Hospital (HUOL) at Federal University of Rio Grande do Norte (UFRN), in Natal County, Rio Grande do Norte State, Brazil. The bile samples that met the inclusion and exclusion criteria were used to select patients from different age groups and genders.

The inclusion criteria were: individuals older than 18 years; the need for bile sample collection during the intraoperative period (i.e., just before cholecystectomy and prior to other associated surgical procedures) as well as the need for immediately sending these samples to microbiological analysis and antibiogram. The exclusion criteria were: the occurrence of emergency surgery; bile sample collected from immunocompromised patients or from patients using immunosuppressive drugs; patients with history of abdominal surgery or of endoscopic interventional procedure in the biliary tract, gallbladder, pancreas or duodenum; and medical records containing incomplete information or information considered insufficient to meet the aim of the current study.

Thirty medical records met the inclusion and exclusion criteria, and the patients had their respective bile samples collected and analyzed through microbiological examination (culture) and antibiogram. Information about the presence of comorbidities, the natural history of diseases and the occurrence of postoperative complications in these medical records was collected.

Patients were divided in two groups, as follows:

- Group of benign diseases (group 1): patients with chronic (calculous and acalculous) cholecystopathy and choledocholithiasis;
- Group of malignant diseases (group 2): patients with duodenal papilla, pancreas, gallbladder and extrahepatic bile duct cancer.

The axillary body temperature equal to or higher than $37.8^{\circ} \mathrm{C}$ was considered fever according to the parameters adopted in the current study. Furthermore, postoperative infectious complications were characterized by fever of known- (determined) or unknown origin (undetermined) detected from the postoperative period until the patient was discharged. Individuals whose medical development complementary serum, urinary laboratory tests and image tests (for etiological research) - did not allow identifying the origin of the infection focus were considered to have fever of undetermined origin. Moreover, cases with at least one type of bacterium in the culture were recorded as bactibilia. The bacteria resistant to two or more different classes of antibiotics, including the beta-lactam antibiotics, during the microbiological examination and the antibiogram were considered to be multiresistant bacteria ${ }^{(14)}$.

The current study was submitted to the Research Ethics Committee of HUOL at UFRN. It was approved under protocol number 925073, since it complied with the Resolution 466/12 of the Brazilian National Health Council, and preserved the complete anonymity of all the individuals participating in the research.

\section{Methodology of the bile microbiological study}

The bile samples were sent to the Laboratory of HUOL at UFRN and subsequently seeded according to the protocol of the Brazilian National Health Surveillance Agency ${ }^{(3)}$, in three culture media, namely: blood agar, MacConkey agar and Mannitol agar. The containers holding the seeded culture media were incubated in an oven at $37^{\circ} \mathrm{C}$, from 24 to 48 hours (only if there was no evidence of bacterial growth in the first 24 hours) after the sowing and stored in containers with microaerophil$\mathrm{ia}^{(3)}$. A microscopic examination was conducted after Gram staining whenever there was bacterial growth as well as other standard biochemical tests (Triple sugar iron; Citrate; Sulfur, indol and motility; Phenyl; Lysine; Ornithine and Malonate), which were manually performed according to the culture medium. Then, an antibiogram was performed using the disk diffusion method or the "Vitek 2 Compact" apparatus, which presents the antibiogram results through the analysis of the minimum inhibitory concentration. The laboratory procedures, from the culture to the final microbiological report with profile resistance, were carried out according to specific protocols and manuals ${ }^{(3,11,21)}$ available in the Laboratory of HUOL at UFRN.

\section{Statistical analysis}

The data collected in the current study were statistically analyzed in the SPSS software. The qualitative variables were analyzed through Pearson's chi-square test or through Fisher's exact test, at 95\% confidence level. 


\section{RESULTS}

Thirty out of the 93 assessed bile samples were selected after the inclusion and exclusion criteria were applied. These samples came from 30 individuals at mean age $\approx 57.7$ years $(\mathrm{SD}=15.6$, range $=22-87)$, mostly women $(\mathrm{n}=18)$ and older than 50 years $(n=23)$. Most of these 30 patients was subjected to laparotomy through abdominal cavity approach $(\mathrm{n}=28)$ (Figure 1).

Twelve out of the 30 selected bile samples were collected from patients with benign diseases (group 1) and 18 from patients with malignant diseases (group 2). Adenocarcinoma of the duodenal papilla $(\mathrm{n}=9)$ and chronic calculous cholecystopathy or cholelithiasis $(\mathrm{n}=8)$ were the most frequent biliopancreatic diseases (basic conditions) (Figure 1).

Twelve bile samples showed bactibilia, most of them were identified in patients with benign biliopancreatic diseases $(8 / 12 ; P=0.024)$. Most of these 12 samples were collected from women $(10 / 12, p=0.058)$ as well as from individuals aged over 50 years $(11 / 12 ; P=0.202)$ (Figure 1$)$.

Eighteen bacteria species were identified in the 12 bile samples that showed positive culture; a single bacteria species was identified in 7 cases, 4 cases showed the simultaneous growth of 2 different bacteria, and 1 case showed the simultaneous growth of 3 different bacteria species. Escherichia coli $(\mathrm{n}=5)$ and Klebsiella $s p(\mathrm{n}=3)$ were the most prevalent bacteria in 8 patients with benign disease; and Klebsiella $s p .(\mathrm{n}=2)$ and Streptococcus $s p .(\mathrm{n}=2)$ were predominant in 4 patients with malignant diseases. Three bile samples showed multiresistant bacteria. No bacterial growth was observed in bile samples from patients with pancreatic adenocarcinoma (Table 1).

The cholecystectomy was performed after the gallbladder wall was punctured in order to collect the bile samples, which were sent for microbiological examination. Subsequently, other associated surgical procedures were conducted in 22 cases. The procedures performed after the bile collection

\begin{tabular}{|c|c|c|c|c|c|}
\hline $\mathbf{N}$ & G & Ag. & Underlying diseases & $\begin{array}{l}\text { Type of surgical } \\
\text { approach }\end{array}$ & $\begin{array}{l}\text { Identified } \\
\text { bacteria }\end{array}$ \\
\hline \multicolumn{6}{|c|}{ GROUP 1} \\
\hline 1 & $\mathrm{~F}$ & 69 & Acalculous CC & Laparotomy & - \\
\hline 2 & $\mathrm{~F}$ & 87 & Calculous $\mathrm{CC}^{\mathrm{a}}$ & Laparotomy & E. coli + Enterococcus sp. \\
\hline 3 & $\mathrm{~F}$ & 51 & Calculous $\mathrm{CC}^{\mathrm{a}}$ & Videolaparoscopy & $\begin{array}{c}\text { Enterobacter } s p^{\mathrm{b}}+\text { Nonfermenter } \\
G N B\end{array}$ \\
\hline 4 & $\mathrm{~F}$ & 53 & Choledochal cyst and calculous CC & Laparotomy & E. coli + Streptococcus sp \\
\hline 5 & $\mathrm{~F}$ & 81 & Choledocolithiasis & Videolaparoscopy & E. coli ${ }^{\text {b }}$ \\
\hline 6 & $\mathrm{~F}$ & 75 & Calculous $\mathrm{CC}^{\mathrm{a}}$ & Laparotomy & - \\
\hline 7 & M & 83 & Choledocolithiasis & Laparotomy & $\begin{array}{l}\text { Klebsiella sp }{ }^{\mathrm{b}}+\text { E. coli }+ \\
\text { ProteusVulgari }\end{array}$ \\
\hline 8 & M & 52 & Calculous CC & Laparotomy & - \\
\hline 9 & $\mathrm{~F}$ & 22 & Calculous CC & Laparotomy & Enterobacter sp. \\
\hline $10^{c}$ & $\mathrm{~F}$ & 55 & Choledocolithiasis & Laparotomy & E. coli + Klebsiella sp \\
\hline 11 & $\mathrm{~F}$ & 61 & Calculous CC & Laparotomy & Klebsiella sp. \\
\hline 12 & $\mathrm{~F}$ & 29 & Calculous CC $^{\mathrm{a}}$ & Laparotomy & - \\
\hline \multicolumn{6}{|c|}{ GROUP 2} \\
\hline 13 & $\mathrm{~F}$ & 63 & Adenocarcinoma of the duodenal papilla & Laparotomy & Klebsiella sp. \\
\hline 14 & M & 44 & Adenocarcinoma of the duodenal papilla & Laparotomy & - \\
\hline 15 & M & 35 & Adenocarcinoma of the duodenal papilla & Laparotomy & - \\
\hline 16 & $\mathrm{~F}$ & 51 & Adenocarcinoma of the duodenal papilla & Laparotomy & Klebsiella sp. \\
\hline 17 & M & 61 & Adenocarcinoma of the duodenal papilla & Laparotomy & Streptococcus sp. \\
\hline 18 & M & 65 & Adenocarcinoma of the duodenal papilla & Laparotomy & - \\
\hline 19 & $\mathrm{~F}$ & 42 & Adenocarcinoma of the duodenal papilla & Laparotomy & - \\
\hline 20 & $\mathrm{~F}$ & 56 & Adenocarcinoma of the duodenal papilla & Laparotomy & - \\
\hline 21 & $\mathrm{M}$ & 66 & Adenocarcinoma of the duodenal papilla & Laparotomy & - \\
\hline 22 & M & 43 & $\begin{array}{c}\text { Cholangiocarcinoma in the distal part of the common bile } \\
\text { duct }\end{array}$ & Laparotomy & - \\
\hline 23 & M & 69 & Adenocarcinoma of the pancreas & Laparotomy & - \\
\hline 24 & M & 74 & Adenocarcinoma of the pancreas & Laparotomy & - \\
\hline 25 & M & 52 & Adenocarcinoma of the pancreas & Laparotomy & - \\
\hline $26^{c}$ & $\mathrm{~F}$ & 51 & Adenocarcinoma of the pancreas & Laparotomy & - \\
\hline 27 & $\mathrm{~F}$ & 69 & Adenocarcinoma of the pancreas & Laparotomy & - \\
\hline 28 & M & 71 & Adenocarcinoma of the pancreas & Laparotomy & - \\
\hline 29 & $\mathrm{~F}$ & 41 & $\begin{array}{l}\text { Cholangiocarcinoma of the middle third of the common } \\
\text { bile duct }\end{array}$ & Laparotomy & - \\
\hline 30 & $\mathrm{~F}$ & 60 & Gallbladder adenocarcinoma (advanced stage) & Laparotomy & Streptococcus sp. \\
\hline
\end{tabular}

FIGURE 1. Distribution of the 30 patients into groups according to gender, age, underlying diseases (biliopancreatic diseases), type of surgical approach and the bacteria species identified in the bile.

N: patient identification; G: gender; Ag.: age in years; CC: chronic cholecystopathy; GNB: gram-negative bacilli; E. coli: Escherichia coli; - : no bacterial growth. ${ }^{a}$ Patients with history of repeated biliary colic crises (more than one episode). ${ }^{b}$ Multiresistant bacteria ${ }^{(14)}$. ${ }^{c}$ Patients on hormone replacement therapy to treat climacteric symptoms. 
TABLE 1. Distribution of bacteria identified in 12 bile samples with positive bile culture, according to patient groups

\begin{tabular}{lccc}
\hline Identified Bacteria & Group 1 & Group 2 & Total \\
\hline Escherichia coli & 5 & 0 & 5 \\
Klebsiella sp. & 3 & 2 & 5 \\
Enterobacter sp. & 2 & 0 & 2 \\
Enterococcus sp. & 1 & 0 & 1 \\
Streptococcus sp. & 1 & 2 & 3 \\
Nonfermenter GNB & 1 & 0 & 1 \\
Proteus Vulgaris & 1 & 0 & 1 \\
Total & 14 & 4 & 18 \\
\hline
\end{tabular}

and the cholecystectomy showed no statistically significant influence on the incidence of postoperative infectious complications $(P=1.0)$ (Figure 2).

Seven patients showed some type of postoperative infectious complications during the postoperative period, and the fever of unknown origin was the most common complication $(n=3)$. There was no explicit statistically significant link between bactibilia and the higher postoperative infectious complication incidence $(P=0.084)$ (Figure 3$)$.
Fourteen out of the 30 patients showed one or more comorbidities. Two cases showed both high blood pressure and diabetes. One case showed hypertension, diabetes and depression, all at once. However, there was no statistically significant difference in bacteria identification in bile samples from patients with and without comorbidities $(P=0.654)$. Hypertension $(n=9)$ and type 2 diabetes mellitus $(n=5)$ were the most common comorbidities (Figure 3 ), they were identified during the preoperative assessment complaint or the clinical jaundice manifestation in 4 patients of group 1 (with 3 individuals with choledocholithiasis) and 16 patients of group 2 (Figure 3 ).

Fourteen out of the 30 patients in the sampling group showed calculi inside the gallbladder; 11 of them belonged to group 1 (Figure 3). Nine of these 14 patients with gallstones showed concomitant bactibilia, although there was no apparent statistically significant link between the presence of gallstones and bactibilia $(P=0.073)$.

The medical records of 11 patients (represented by numbers $2,5,11,14,16,19,21,22,23,27$ and 28) from the total sampling group presented upper digestive endoscopy results. Only one patient $\left(\mathrm{n}^{\circ} .11\right)$ presented Helicobacter pylori in the urease test.

\begin{tabular}{|c|c|c|}
\hline GROUPS & $\mathbf{N}$ & ASSOCIATED SURGICAL PROCEDURES PERFORMED AFTER BILE COLLECTION AND CHOLECYSTECTOMY \\
\hline \multirow{12}{*}{ GROUP 1} & 1 & No procedure associated with CCT \\
\hline & 2 & No procedure associated with CCT \\
\hline & 3 & No procedure associated with CCT \\
\hline & 4 & Cyst resection in the common bile duct and intrahepatic biliodigestive anastomosis (hepatic-jejunal) \\
\hline & 5 & Choledochotomy + biliodigestive anastomosis (hepatoduodenal) \\
\hline & 6 & No procedure associated with CCT \\
\hline & 7 & Choledochotomy + biliodigestive anastomosis (choledochusduodenal) \\
\hline & 8 & No procedure associated with CCT \\
\hline & 9 & No procedure associated with CCT \\
\hline & 10 & Choledochotomy, suture of common bile duct and placement of Kehr's drain \\
\hline & 11 & No procedure associated with CCT \\
\hline & 12 & No procedure associated with CCT \\
\hline \multirow{18}{*}{ GROUP 2} & 13 & GDP and abdominal cavity draining ${ }^{\mathrm{a}}$ \\
\hline & 14 & GDP, liver biopsy and abdominal cavity draining ${ }^{a}$ \\
\hline & 15 & GDP and abdominal cavity draining ${ }^{\mathrm{a}}$ \\
\hline & 16 & GDP and abdominal cavity draining ${ }^{\mathrm{a}}$ \\
\hline & 17 & GDP and abdominal cavity draining ${ }^{a}$ \\
\hline & 18 & GDP and abdominal cavity draining ${ }^{\mathrm{a}}$ \\
\hline & 19 & GDP and abdominal cavity draining ${ }^{\mathrm{a}}$ \\
\hline & 20 & GDP and abdominal cavity draining ${ }^{a}$ \\
\hline & 21 & GDP and abdominal cavity draining ${ }^{\mathrm{a}}$ \\
\hline & 22 & GDP, liver biopsy and abdominal cavity draining ${ }^{a}$ \\
\hline & 23 & GDP and abdominal cavity draining ${ }^{a}$ \\
\hline & 24 & GDP and abdominal cavity draining ${ }^{\mathrm{a}}$ \\
\hline & 25 & GDP and abdominal cavity draining ${ }^{\mathrm{a}}$ \\
\hline & 26 & GDP and abdominal cavity draining ${ }^{\mathrm{a}}$ \\
\hline & 27 & GDP and abdominal cavity draining ${ }^{a}$ \\
\hline & 28 & GDP and abdominal cavity draining ${ }^{\mathrm{a}}$ \\
\hline & 29 & $\begin{array}{l}\text { Tumor resection in the middle third of the biliary tract } \\
\text { and biliodigestive anastomosis (choledochojejunostomy) }\end{array}$ \\
\hline & 30 & $\begin{array}{l}\text { Resection of the biliary tract and biliodigestive anastomosis } \\
\text { (choledochojejunostomy) }\end{array}$ \\
\hline
\end{tabular}

FIGURE 2. Distribution of associated surgical procedures performed after bile collection and cholecystectomy.

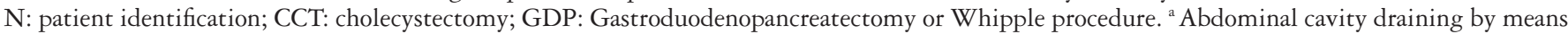
of two siliconized tubular-laminar drains.

Note: The text highlighted in bold identifies patients who developed postoperative infectious complications. 


\begin{tabular}{|c|c|c|c|c|c|}
\hline $\mathbf{N}$ & $\begin{array}{c}\text { Identified } \\
\text { bacteria }\end{array}$ & $\begin{array}{c}\text { Jaundice } \\
\text { preoperatively }\end{array}$ & Comorbidities & $\begin{array}{l}\text { Postoperative infectious } \\
\text { complications }\end{array}$ & $\begin{array}{l}\text { Hospital stay } \\
\text { (in days) }\end{array}$ \\
\hline \multicolumn{6}{|c|}{ GROUP 1} \\
\hline 1 & - & NO & Hypothyroidism & \multirow{2}{*}{$\begin{array}{c}\text { Absent } \\
\text { Sepsis by intra-abdominal origin } \\
\text { focus }\end{array}$} & 16 \\
\hline $2^{a}$ & E. coli and Enterococcus sp & NO & Absent & & 33 \\
\hline $3^{a}$ & $\begin{array}{l}\text { Enterobacter } s p^{\mathrm{b}} \text { and } \\
\text { Nonfermenter } G N B\end{array}$ & YES & $\mathrm{SAH}$ & Absent & 53 \\
\hline $4^{\mathrm{a}}$ & E. coli and Streptococcus sp & YES & Absent & Absent & 11 \\
\hline $5^{a}$ & E. coli ${ }^{\mathrm{b}}$ & YES & $\begin{array}{l}\text { SAH, Diabetes } \\
\text { and Depression }\end{array}$ & Absent & 14 \\
\hline $6^{a}$ & - & NO & SAH & Absent & 4 \\
\hline $7^{\mathrm{a}}$ & $\begin{array}{l}\text { Klebsiella sp } p^{\mathrm{b}}, \text { E. coli and } \\
\text { Proteus Vulgaris }\end{array}$ & NO & $\mathrm{BPH}$ & Surgical wound infection & 9 \\
\hline $8^{\mathrm{a}}$ & - & NO & Absent & Absent & 9 \\
\hline $9^{a}$ & Enterobacter $s p$ & NO & Absent & Absent & 2 \\
\hline $10^{\mathrm{a}, \mathrm{c}}$ & E. coli and Klebsiella sp & YES & SAH & Absent & 9 \\
\hline $11^{\mathrm{a}}$ & Klebsiella sp & NO & Diabetes & Absent & 3 \\
\hline $12^{\mathrm{a}}$ & - & NO & Absent & Absent & 8 \\
\hline & GROUP 2 & & & & \\
\hline $13^{\mathrm{a}}$ & Klebsiella sp & YES & SAH, Diabetes, & UTI & 51 \\
\hline $14^{\mathrm{a}}$ & - & YES & Absent & Absent & 37 \\
\hline 15 & - & YES & Absent & Absent & 37 \\
\hline 16 & Klebsiella sp & YES & Absent & Absent & 21 \\
\hline 17 & Streptococcus sp & YES & Absent & Undetermined fever & 44 \\
\hline 18 & - & YES & Absent & Absent & 19 \\
\hline $19^{\mathrm{a}}$ & - & YES & Absent & Absent & 15 \\
\hline 20 & - & NO & SAH & Absent & 59 \\
\hline 21 & - & YES & Absent & Absent & 36 \\
\hline 22 & - & YES & Absent & Absent & 58 \\
\hline 23 & - & YES & SAH and Diabetes & Absent & 30 \\
\hline 24 & - & YES & SAH & Absent & 33 \\
\hline 25 & - & YES & Diabetes & Absent & 23 \\
\hline $26^{c}$ & - & YES & Depression & UTI & 11 \\
\hline 27 & - & YES & Absent & Absent & 21 \\
\hline 28 & - & YES & SAH & Undetermined fever & 20 \\
\hline 29 & - & NO & Absent & Absent & 13 \\
\hline 30 & Streptococcus sp & YES & Absent & Undetermined fever & 17 \\
\hline
\end{tabular}

FIGURE 3. Distribution of the 30 patients per group, bacteria identified in the bile, presence of jaundice in the preoperative period, comorbidities, occurrence of postoperative infectious complications and time of hospital stay.

N: patient identification; - : no bacterial growth; GNB: Gram-negative bacilli; E. coli: Escherichia coli; SAH: systemic arterial hypertension; Diabetes: type 2 diabetes mellitus; BPH: benign prostatic hyperplasia; UTI: urinary-tract-originated infection. ${ }^{a}$ Patients with gallstones. ${ }^{\mathrm{b}}$ Multiresistant bacteria.

${ }^{\mathrm{c}}$ Patients on hormone replacement therapy to treat climacteric symptoms.

\section{DISCUSSION}

Bactibilia was identified in the bile culture of 12 patients. Most of these patients had benign diseases. Bactibilia is uncommon in patients with biliopancreatic cancers and it is particularly absent in pancreatic adenocarcinoma cases. Although bactibilia was identified in four patients with malignant diseases, the sample size did not allow associating the presence of any bacteria in the bile to biliopancreatic cancer, despite the attempt in other studies to demonstrate such an association $^{(6,12,16-19,22,23,25,28,30)}$, mainly between gallbladder cancer and the presence of Salmonella typhi $i^{(16,17,22,23,25)}$ and/ or Salmonella paratyphi ${ }^{(17,23,22)}$. Moreover, as for the present study, the predominant bacterial flora identified in patients with malignant neoplasia was a bit different from that of patients with benign diseases. There was Streptococcus $s p$ predominance in patients with cancer. Although a rare case report tries to link the existence of bacteremia caused by Streptococcus bovis to gallbladder cancer formation, it was not possible to consolidate evidences to infer or suggest any significant association between them ${ }^{(19)}$. On the other hand, Escherichia coli and Klebsiella sp were the most common bacteria in patients with benign biliopancreatic diseases. Three bile samples showed multiresistant bacteria (Figure 1).

Nine out of the 14 patients with gallstones showed concomitant bactibilia (Figure 3). It is worth highlighting that the absence of bactibilia in patients with gallstones may have been influenced by the bacteria ability of forming biofilms in the periphery of the gallstones, as well as by their habit of keeping on colonizing just the gallbladder wall without dispersing into the bile. Such feature may have generated some false negative results. This process could explain why the bile cultures showed no bacterial growth in patients with gallstones ${ }^{(28)}$. 
Comorbidities were found in 14 patients and bactibilia was identified in six cases, in the current study. Systemic arterial hypertension and type 2 diabetes mellitus were the most common comorbidities found in these six individuals. Contrary to what some studies have tried to suggest, none of the herein observed comorbidities represented a significant risk of bactibilia incidence increase ${ }^{(5)}$.

Five out of the seven patients who showed postoperative infectious complications in the present study had bactibilia. It may suggest that patients tend to have higher incidence of these complications when there are bacteria in their bile, although there was no statistical significance to prove it in the current study $(P=0.084)$. Such concept is justified if one considers a confidence level of $90 \%$, although our study did not show statistically significant evidence at $95 \%$ confidence level $(P<0.05)$. This result $(P<0.10)$ would be statistically significant and reinforced if the research was done using larger samples (larger $\mathrm{N})$. In this case, we would have reached significant values at $95 \%$ confidence level as it was evidenced in other studies ${ }^{(7,8,24)}$.

The aforementioned trend may be strengthened by some significant results shown in other studies ${ }^{(1,7,8,24)}$, although most of these studies are restricted to patients with acute lithiasic cholecystitis ${ }^{(1,8,24)}$. The present study could have found a significant link between bactibilia and the presence of postoperative infectious complications if a larger sample had been used ${ }^{(7)}$. However, it is noteworthy that half of the sample was composed of individuals aged 60 years or older and this alone could have influenced the incidence of bactibilia $^{(6,8,20,24)}$ and, consequently, the occurrence of postoperative infectious complications ${ }^{(8,24)}$.

Moreover, it is worth emphasizing that the current study found that women tend to present higher bactibilia incidence
$(P=0.058)$, and it corroborates the results from other studies ${ }^{(9,10)}$. However, it should be taken into account that gallstone incidence in women is two-to-three-times higher due to the estrogenic activity, which could favor the occurrence of bactibilia among women ${ }^{(4)}$. Therefore, one may assume the possibility of developing a microbiological study of the bile in over-50-year-old women subjected to cholecystectomy due to biliopancreatic diseases as a way to improve the antibiotic prophylaxis and the antibiotic therapy, as well as to prevent possible postoperative infectious complications in the future, particularly those associated with multiresistant bacteria.

\section{CONCLUSION}

Bactibilia was found in 12 samples and the most identified bacteria in patients with benign diseases were Escherichia coli and Klebsiella sp. Streptococcus sp and Klebsiella sp were prevalent in cancer patients. There was a trend for higher postoperative infectious complication incidence in patients with bactibilia.

\section{Authors' contributions}

Alves JR mentored medical students in the literature review and data collection, and he was the final reviewer of the article writing, and responsible for the translation into English, as well as for the text formatting and for the process of submitting the article. Amico EC contributed to the revision of the article writing. Souza DLB performed the statistical analysis and contributed to the final revision. Silva RC, Guerra SCP and Freitas TT conducted a literature review and participated in the writing of the manuscript. All authors read and approved the final version of the article.

Alves JR, Silva RC, Guerra SCP, Freitas TT, Souza DLB, Amico EC. Análise microbiológica da bile em pacientes com doenças biliopancreáticas benignas e malignas e suas consequências. Arq Gastroenterol. 2016,53(3):156-62.

RESUMO - Contexto - Bacteriobilia pode produzir várias consequências para a saúde humana. Objetivo - Avaliar a microbiologia da bile de pacientes com doenças biliopancreáticas para identificar bactérias e possíveis consequências. Métodos - Estudo retrospectivo microbiológico. Trinta amostras de bile de pacientes com doenças biliopancreáticas benignas e malignas foram avaliadas para determinar a flora microbiológica da bile e procurar alguma possível relação dessa com comorbidades, carcinogênese e complicações infecciosas pós-operatórias. Resultados - As amostras de bile foram avaliadas em pacientes, com idade média $\approx 57,7$ anos, a maioria mulheres $(n=18)$. Evidenciou-se bacteriobilia em 12 casos, a maioria em pacientes com doenças benignas $(n=8)$; pacientes com mais de 50 anos $(n=23)$ e mulheres $(n=10)$. As doenças mais comuns foram o adenocarcinoma de papila duodenal $(\mathrm{n}=9)$ e a colelitíase $(\mathrm{n}=8)$. Escherichia coli $(\mathrm{n}=5)$ e Klebsiella $\mathrm{sp}(\mathrm{n}=5)$ foram as bactérias mais identificadas em pacientes com doenças benignas; sendo a Klebsiella $s p(\mathrm{n}=2)$ e o Streptococcus $s p(\mathrm{n}=2)$ as que predominaram nos pacientes com cânceres. As complicações pós-operatórias exclusivamente infecciosas ocorreram em sete casos, sendo em cinco desses associados à bacteriobilia $(P=0,084)$. Conclusão - Bacteriobilia foi evidenciada em

12 amostras, sendo as bactérias mais identificadas Escherichia coli e Klebsiella sp em pacientes com doenças benignas; e Streptococcus sp e Klebsiella $s p$ nos pacientes com câncer. Existiu uma tendência a maior incidência de complicações infecciosas pós-operatórias em pacientes com bacteriobilia.

DESCRITORES - Microbiologia. Bile. Colecistectomia. Complicações pós-operatórias. Carcinogênese. 


\section{REFERENCES}

1. Baitello AL, Colleoni NR, Herani FB, Cordeiro JA, Machado AMO, Godoy MF, et al. Bacteremia - prevalence and associated factors in patients with acute calculous cholecystitis. Rev Assoc Med Bras. 2004;50:373-9.

2. Barrett KE. Fisiologia Gastrointestinal. $2^{\mathrm{a}}$ ed. Ed. AMGH Editora Ltda, Porto Alegre - RS. 2015.

3. Brasil. Agência Nacional de Vigilância Sanitária. Manual de Microbiologia Clínica para controle de infecção relacionada ao sistema de saúde. Módulo 4: Procedimentos laboratoriais: da requisição do exame à análise microbiológica e laudo final. Brasília: Anvisa; 2013.

4. Brow AC, Wrenn SP, Suresh N, Meyers WC, Abedin MC. Gender differences in cholesterol nucleation in native bile: Estrogen is a potential contributory factor. $\mathrm{J}$ Membr Biol. 2009;232:35-45.

5. Chao CM, Lai CC, Tang HJ, Ko WC, Hsueh PR. Biliary tract infections caused by Aeromonas species. Eur J Clin Microbiol Infect Dis. 2013;32:245-51.

6. Csendes A, Becerra M, Burdiles P, Demian I, Bancalari K, Csendes P. Bacteriological studies of bile from the gallbladder in patients with carcinoma of the gallbladder, cholelithiasis, common bile duct stones and no gallstones disease. Eur J Surg. 1994;160:363-7.

7. Darkahi B, Sandblom G, Lijeholm H, Videhult P, Melhus A, Rasmussen IC. Biliary microflora in patients undergoing cholecystectomy. Surg Infect. 2014; 15:262-5.

8. Galili O, Eldar S Jr, Matter I, Madi H, Brodsky A, Galis I, et al. The effect of bactibilia on the course and outcome of laparoscopic cholecystectomy. Eur J Clin Microbiol Infect Dis. 2008;27:797-803.

9. Kai K, Aishima S, Miyazaki K. Gallbladder cancer: Clinical and pathological approach. World J Clin Cases. 2014;2:515-21.

10. Kianmanesh R, Scaringi S, Castel B, Flamant Y, Msika S. Precancerous lesions of the gallbladder. J Chir (Paris). 2007;144:278-86.

11. Koneman EW, Allen SD, Janda WM, Schreckenberger PC, Winn Jr. WC. Diagnóstico microbiológico: texto e atlas colorido. 5. ed. São Paulo: Medsi editora; 2001.

12. Lax AJ, Thomas W. How bacteria could cause cancer: one step at a time. Trends in Microbiol. 2002;10:293-9.

13. Losada H, Manterola D, Pineda V, Vialg M. Recuento bacteriano em bilis de pacientes com colangitis aguda: Reporte preliminar. Rev Chil Cir. 2006;58:35-9

14. Mattos AA, Costabeber AM, Lionço LC, Tovo CV. Multi-resistant bacteria in spontaneous bacterial peritonitis: A new step in management? World J Gastroenterol. 2014;20:14079-86.

15. Mohammed S, Evans C, VanBuren G,_Hodges SE, Silberfein E, Artinyan A, et al. Treatment of bacteriobilia decreases wound infection rates after pancreaticoduodenectomy. HPB (Oxford). 2014;16:592-8.
16. Nath G, Gulati AK, Shukla VK. Role of bacteria in carcinogenesis, with special reference to carcinoma of the gallbladder. World J Gastroenterol. 2010;16:5395-404

17. Nath G, Singh H, Shukla VK. Chronic typhoid carriage and carcinoma of the gall bladder. Eur J Cancer Prev. 1997;6:557-9.

18. Nilsson HO, Stenram U, Ihse I, Wadstrom T. Helicobacter species ribosomal DNA in the pancreas, stomach and duodenum of pancreatic cancer patients. World J Gastroenterol. 2006;12:3038-43.

19. O'Brien B, Dyer B, DeLuca J, Richmond BK. Streptococcus bovis bacteremia as the initial presentation of carcinoma of the gallbladder. W V Med J. 2014;110:32-3.

20. Ohdan $\mathrm{H}$, Oshiro $\mathrm{H}$, Yamamoto $\mathrm{Y}$, Tanaka I, Inagaki K, Sumimoto K, et al. Bacteriological investigation of bile in patients with cholelithiasis. Surg Today. 1993;23:390-5.

21. Oplustil CP, Zoccoli CM, Tobouti NR, Sinto SI. Procedimentos básicos em microbiologia clínica. 3. ed. São Paulo: Sarvier editora; 2010.

22. Pilgrim CH, Groeschl RT, Christians KK, Gamblin TC. Modern perspectives on factor predisposing to the development of gallbladder cancer. HPB (Oxford). 2013;15:839-44.

23. Randi G, Franceschi S, La Vecchia C. Gallbladder cancer worldwide: geographical distribution and risk factors. Int J Cancer. 2006;118:1591-602.

24. Rico RC, Linares JRS, Polo FC, Vázquez MTP, Rojas JLV, Estévez MD, et al Bacteriologic findings as a prognostic factor in the course of acute cholecystitis. Rev Esp Enferm Apar Dig. 1989;76:465-70.

25. Samaras V, Rafailidis PI, Mourtzoukou EG, Peppas G, Falagas ME. Chronic bacterial and parasitic infections and cancer: a review. J Infect Dev Ctries. 2010;4:267-81.

26. Sharma V, Chauhan VS, Nath G, Kumar A, Shukla VK. Role of bile bacteria in gallbladder carcinoma. Hepatogastroenterology. 2007; 54:1622-1625.

27. Sung JY, Costerton JW, Shaffer EA. Defense system in the biliary tract against bacterial infection. Dig Dis Sci. 1992;37:689-96.

28. Swidsinski A, Lee SP. The role of bacteria in gallstone pathogenesis. Front Biosci. 2001;1:e93-103.

29. World Health Organization, International Agency for Research on Cancer. A review of human carcinogens. IARC Monogr Eval Carcinog Risks Hum, Part B: Biological agents; 2009. p.402-3.

30. Zhou D, Wang JD, Weng MZ, Zhang Y, Wang XF, Gong W, et al. Infections of Helicobacter spp. in the biliary system are associated with biliary tract cancer: a meta-analysis. Eur J Gastroenterol Hepatol. 2013;25:447-54. 